\title{
STRATEGI PEMASARAN, SITUASI PERSAINGAN, DAN PERMODALAN DALAM MEMPENGARUHI KINERJA UKM PENGRAJIN TERASI KAWASAN PESISIR KOTA LANGSA
}

\author{
Submitted Date : \\ 12 Nopember 2019 \\ Accepted Date : \\ 25 Nopember 2019
}

\author{
Muhammad Rizqi Zati \\ Universitas Samudra \\ Rizqi_zati@unsam.ac.id
}

Dhian Rosalina*,

Universitas Samudra

dhian.rosalina@unsam.ac.id

Dyah Ayu Ardiyanti

Universitas Samudra Langsa

dyahsangayu@gmail.com

\section{Suggested citation :}

Irjayanti, M., \& Azis, A. M. (2013). Barrier Factors and Potential Solutions for Indonesian SMEs. Procedia Economics and Finance, 4(Icsmed), 3-12.

\section{Abstract :}

This study aims to analyze the effect of marketing strategies, competitive situations, and capital on the performance of shrimp paste SMEs in the coastal area of Langsa City. The number of respondents in this study was twenty-four shrimp paste in the coastal area of Langsa City in two villages: Lhokbani and Simpang Lhee which are craftsmen centers for shrimp paste / rebon shrimp paste in Langsa City. The sampling technique used is non probablity sampling. The analytical method used is multiple linear regression analysis. The results of this study are 1) Marketing strategies do not have a significant impact on business performance, 2) The competitive situation does not have a significant impact on business performance, and 3) capital has a positive and significant effect. From the results of the analysis it was found that this research was consistent with previous research that the problem of capital was still a serious obstacle for small and medium businesses in Indonesia.

Keywords: Small and Medium Enterprises, Regression Analysis, Capital

\section{Abstrak:}

Penelitian ini bertujuan untuk menganalisis pengaruh strategi pemasaran, situasi persaingan, dan permodalan terhadap kinerja UKM terasi di wilayah pesisir Kota Langsa. Jumlah responden dalam penelitian ini adalah dua puluh empat pengrajin terasi di wilayah pesisir Kota Langsa di dua desa: Lhokbani dan Simpang Lhee yang merupakan sentra pengrajin terasi / pasta udang rebon di Kota Langsa. Teknik pengambilan sampel yang digunakan adalah non probablity sampling. Metode analisis yang digunakan adalah analisis regresi linier berganda. Hasil dari penelitian ini adalah 1) Strategi pemasaran tidak memiliki dampak yang signifikan terhadap kinerja bisnis, 2) Situasi persaingan tidak memiliki dampak yang signifikan terhadap kinerja bisnis, dan 3) modal memiliki pengaruh positif dan signifikan. Dari hasil analisis diketahui bahwa penelitian ini konsisten dengan penelitian sebelumnya bahwa masalah permodalan masih menjadi kendala serius bagi usaha kecil dan menengah di Indonesia.

Kata Kunci : Usaha kecil dan menengah, Analisis regresi, Permodalan 


\section{Pendahuluan}

Indonesia mengalami tantangan dalam bidang ketenaga kerjaan, banyaknya jumlah penduduk tidak sebanding dengan presentase penyerapan angkatan kerja. Berdasarkan data dari Badan Pusat Statistik (BPS) mengungkapkan bahwa pada tahun 2017 telah terjadi kenaikan jumlah pengangguran di Indonesia sebesar 10.000 orang menjadi 7,04 juta orang pada bulan Agustus 2017 dari Agustus 2016 sebesar 7,03 juta orang. Khusus Untuk wilayah Aceh, BPS mencatat bahwa tingkat penggangguran mengalami penurunan meskipun masih cukup tinggi, yaitu pada tahun 2014 per Agustus adalah sebesar 9,02\%, tahun 2015 sebesar 9,93\%, diikuti tahun $20167,57 \%$, sampai dengan per Agustus tahun 2017 adalah sebesar 6,57\% dari total angkatan kerja yang berada di wilayah Nanggroe Aceh Darussalam (BPS, 2019), dimana jika diurai berdasarkan pendidikan jumlah penggangguran berasal dari lulusan Sekolah Dasar yaitu 655.000 orang $(30,64 \%)$, tingkat pendidikan SMA Umum 582.000 orang (27,24\%), tingkat pendidikan SMP sebanyak 444.000 orang $(20,75 \%)$, tingkat diploma dan universitas 363.000 orang $(16,98 \%)$ dan terakhir lulusan SMK 94.000 orang $(4,39 \%)$ (BPS, 2019).

Pertumbuhan jumlah Usaha Kecil dan Menengah di Aceh juga mengalami sedikit penurunan, pada tahun 2013 tercatat jumlah pelaku usaha sebesar 75.568 orang, diikuti tahun 2014 sebanyak 71.031 orang, dan tahun 2015 sebanyak 65.492 orang (BPS, 2019), yang mana untuk tahun 2016 dan 2017 belum di publish dalam situs resmi BPS. Adanya kecenderungan penurunan jumlah pelaku usaha harus ditanggapi serius, mengingat bahwa pelaku usaha memiliki kontribusi yang sangat tinggi dalam pemberdayaan ekonomi masyarakat.

Dari data statistik di atas, sangat jelas bahwa pelaku usaha kecil dan menengah perlu mendapatkan dukungan guna memperkuat ekonomi masyarakat. Usaha pemerintah dan para pelaku usaha sering menghadapi kendala, dimana kendala tersebut dibagi menjadi dua (Yuwono et al., 2007): pertama adalah hambatan internal (kurangnya permodalan, sumber daya manusia yang terbatas, lemahnya jaringan usaha dan penetrasi pasar), kedua adalah hambatan eksternal (iklim usaha belum kondusif, terbatasnya sarana dan prasarana). Pengelolaan kendala usaha harus dilakukan dengan tepat karena Usaha Kecil dan Menengah adalah bentuk kemandirian ekonomi yang memiliki dampak yang luas bagi masyarakat dan negara. Secara spesifik (Tambunan, T., 2005) menyebutkan bahwa pelaku usaha kecil menghadapi beberapa kendala khusus seperti manajemen keuangan dan manajemen bisnis, yaang menyebabkan usaha yang digeluti pelaku usaha kecil sulit berkembang. Dalam penelitian yang dilakukan oleh Indarti dan Langenberg (2004), menemukan bahwa terdapat contextual variables yang terdiri dari marketing, teknologi, dan permodalan yang berpengaruh secara positif dan signifikan terhadap keberhasilan usaha kecil dan menengah. Penelitian tersebut diperkuat oleh (Irjayanti \& Azis, 2013) menemukan bahwa ada sepuluh hambatan potensial secara umum yang dihadapi pelaku usaha kecil, yaitu : persaingan, akses finansial, sumber daya energi, teknologi, biaya produksi yang tidak efisien, kebijakan ekonomi pemerintah, keahlian, proses produksi, keterbatasan penjualan, dan bahan mentah.

Kota Langsa adalah salah satu Kota di ujung timur Aceh dengan total populasi adalah 184.424 jiwa (BPS, 2019). Letak Kota Langsa cukup strategis karena berdekatan dengan pantai yang merupakan sumber bahan baku bagi masyarakat kawasan tersebut untuk diolah menjadi produk ekonomis. Salah satu produk yang menjadi penggerak ekonomi wilayah pesisir adalah terasi. Berdasarkan hasil pengamatan peneliti. Pemasaran terasi sendiri lebih banyak mengandalkan pemasaran tradisional, dimana para pembeli terasi akan menginformasikan kualitas terasi langsa kepada orang lain dengan cara membelikan oleh - oleh baik di provinsi Aceh, Sumatera, sampai dengan pulau Jawa, bahkan sampai dengan luar negeri. Meskipun demikian produk terasi Langsa masih belum mampu menguasai pasar nasional, akibat akses finansial yang terbatas dalam menangani permintaan yang tinggi. ituasi persaingan yang cukup ketat dalam olahan pangan berbasisi udang, sehingga memerlukan dukungan berbagai pihak bagi perkembangan usaha para pengrajinnya.

Berdasarkan permasalahan di atas, maka tujuan dari penelitian ini adalah sebagai berikut: a) Menganalisis pengaruh strategi pemasaran terhadap pertumbuhan usaha terasi Kota Langsa, b) Menganalisis situasi persaingan terhadap pertumbuhan usaha terasi Kota langsa dan c) Menganalisis faktor permodalan terhadap pertumbuhan usaha terasi Kota langsa. 


\section{Faktor - Faktor Penghambat Usaha Kecil}

Menurut Scarborough \& Zimmerer,2005 dalam (Hadiyati, 2011) menyatakan bahwa dalam pemulihan krisis ekonomi di Indonesia berjalan selama tujuh tahun menunjukkan bahwa ekonomi Indonesia tidak hanya mengandalkan peranan usaha besar, tetapi UMKM terbukti mem-punyai ketahanan relatif lebih baik dibandingkan dengan usaha skala lebih besar. Keandalan Usaha Mikro, Kecil dan Menengah didukung oleh pemerintah dengan program pemberdayaan UKM. Menurut Undang-Undang Nomor 20 Tahun 2008 menjelaskan bahwa tujuan dari pemberdayaan usaha mikro, kecil dan menengah: adalah sebagai berikut :

a. Mewujudkan stuktur ekonomi perekonomian nasional yang seimbang, berkembang, dan ber-keadilan.

b. Menumbuh dan mengembangkan kemampuan usaha mikro, kecil dan menengah menjadi usaha yang tangguh dan mandiri, dan;

c. Meningkatkan peran mikro, kecil dan menengah dalam pembangunan daerah, penciptaan lapangan pekerjaan, pemerataan pendapatan, pertumbuhan ekonomi dan pengentasan rakyat dari kemiskinan.

Dari berbagai kajian dan upaya-upaya pembinaan usaha ekonomi rakyat di Indonesia, permasalahan yang seringkali dihadapi antara lain meliputi: akses pasar, pembiayaan usaha, rendahnya kemampuan teknik produksi dan kontrol kualitas, manajemen secara umum (Adawiyah,2015). (Purwaningsih \& Kusuma Damar, 2015), Shujiro Urata (2000) yang melakukan penelitian pada UKM di tujuh kota besar di Indonesia berhasil mengidentifikasikan permasalahan UKM yang meliputi: lemahnya akses pasar $(29 \%)$, keuangan $(19,2 \%)$, informasi teknik dan pelatihan $(19,2 \%)$, kontrol kualitas, manajemen, peralatan produksi masing-masing $9,6 \%$ dan masalah lain $4 \%$.

\section{Strategi Pemasaran}

Dalam konteks bisnis, strategi dapat diartikan gambaran arah bisnis yang mengikuti lingkungan yang dipilih dan menjadi pedoman dalam mengalokasikan sumber daya dan usaha organisasi (Purwaningsih \& Kusuma Damar, 2015). Strategi pemasaran merupakan perluasan tindakan yang diambil untuk memasarkan produk, yang menggambarkan perbedaan berarti dari pelaksanaan strategi pemasaran (A. Utaminingsih, 2016). Setiap pelaku UKM harus memahami bahwa strategi pemasaran merupakan salah satu keunggulan bersaing yang berkesinambungan dalam memproduksi barang dan jasa (Wibowo, Arifin, \& Sunarti, 2015). Dengan strategi pemasaran yang efektif dapat membantu pelaku usaha kecil mendapatkan keunggulan kompetitif (Kumar, Sheetal, \& Sangeeta, 2012), sehingga kinerja pelaku usaha kecil pun meningkat.

\section{Permodalan}

Sumber modal berasal dari tabungan, modal keluarga, regulasi mengenai kredit bank (Indarti \& Langenberg, 2004). Masalah utama pelaku kecil di Indonesia adalah kekurangan modal usaha, melihat sedikitnya pelaku usaha kecil yang dapat mengakses bantuan modal pinjaman dari lembaga keuangan (Irjayanti \& Azis, 2013). Kajian yang dilakukan oleh (Adawiyah, 2011) juga menyebutkan bahwa permodalan masih menjadi masalah utama bagi pelaku usaha kecil di Indonesia. Akses modal yang terbatas menyebabkan pelaku usaha kecil di Indonesia masih mengandalkan modal sendiri (Yuwono et al., 2007). Permasalahan permodalan tersebut berimbas kepada keterbatasan pelaku usaha kecil memenuhi permintaan pasar dalam jumlah besar dan mengganggu kinerja.

\section{Situasi Persaingan}


Lingkungan persaingan adalah salah satu faktor yang mendukung kinerja pelaku usaha kecil. Usaha Kecil dan Menengah yang dapat bertahan dari lingkungan bisnis membutuhkan kemampuan untuk menyesuaikan diri dengan dinamika pasar dan teknologi yang mendukung kinerja..(Wardi, Susanto, \& Abdullah, 2017), yang mana lingkungan persaingan bisnis meliputi intensitas persaingan, turbulensi pasar dan teknologi.

\section{Kinerja}

Kinerja adalah segala sesuatu yang berhubungan dengan aktivitas dan hasil yang diperoleh (A. Utaminingsih, 2016). Kinerja perusahaan adalah hasil dari banyak keputusan individu yang dibuat secara terus menerus oleh manajemen (Ediraras, 2010). Kinerja perusahaan didefinisikan sebagai kemampuan perusahaan untuk membuat tindakan dan hasil yang dapat diterima (Samir \& Larso, 2002), yang dapat dilihat dari kepuasan pemilik atas profit, omset, dan tahap balik modal (BEP). Menurut Pribadi dan Kanai (2011), kinerja usaha kecil dan menengah dipengaruhi oleh oleh tiga hal yaitu : faktor internal, faktor eksternal, dan ukuran perusahaan. Sedangkan Empat faktor rendahnya kinerja usaha kecil dan menengah adalah antara lain disebabkan :

1. Penggunaan teknologi tradisonal

2. Pangsa pasar menurun karena modal

3. Tidak memiliki kelengkapan administrasi sebagay syarat pinjaman bank

4. Tingkat ketergantungan tinggi terhadap fasilitas pemerintah (Ardiana dan Subaedi, 2010)

\section{Kerangka Teoritis dan Hipotesis}

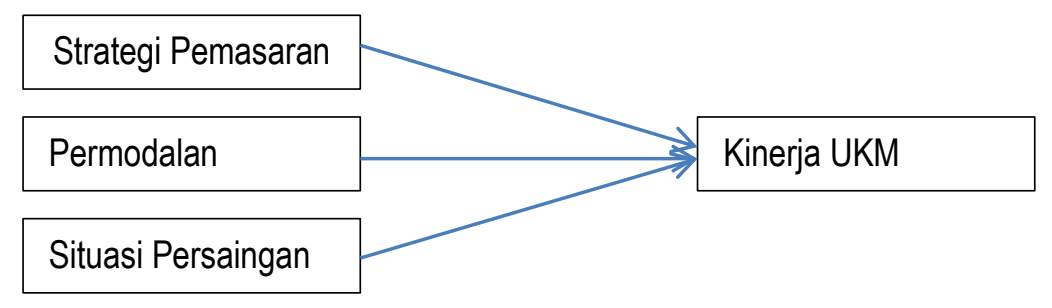

Gambar 1. Kerangka Penelitian

Berdasarkan dari permasalahan dan kerangka teoritis yang telah diuaraikan di atas, maka hipotesis penelitian ini adalah sebagai berikut :

Hipotesis 1 : Strategi pemasaran berpengaruh positif dan signifikan terhadap kinerja UKM

Hipotesis 2: Permodalan berpengaruh positif dan signifikan terhadap kinerja UKM

Hipotesis 3 : Situasi persaingan berpengaruh positif dan signifikan terhadap kinerja UKM

\section{Metode Penelitian}

Penelitian ini berjenis deskriptif kuantitatif, dengan mencari faktor - faktor dominan yang menghambat perkembangan usaha pengrajin terasi di kawasan pesisir Kota Langsa, analisis yang digunakan adalah analisis regresi berganda . instrumen yang digunakan adalah angket, dikombinasikan bersama wawancara mendalam (in depth interviews) yang menggali informasi mengenai keinginan, harapan responden terhadap permasalahan yang dihadapi. Kuesioner yang digunakan terdiri dari tiga bagian yaitu bagian pertama adalah profil demografis responden dan petunjuk pengisian, bagian kedua adalah pernyataan pernyataan yang diisi responden dengan opsi sangat setuju sampai dengan sangat tidak setuju, dengan skala Likert 1-5. Bagian ketiga adalah butir pertanyaan tambahan mengenai upaya pemerintah yang sudah dilakukan untuk membantu pelaku usaha terasi Kota Langsa dan bagaimana dampak bantuan tersebut kepada jalannya usaha.

Metode non probabilitas digunakan dalam pemilihan sampel. Hal ini disebabkan karena populasi penelitian tidak diketahui oleh peneliti, artinya setiap elemen di dalam populasi tidak memiliki probabilitas yang sama untuk 
dipilih menjadi sampel atau pemilihan anggota sampel ditentukan dengan tidak acak. Terdapat beberapa pertimbangan peneliti memilih pengambilan teknik non probabilitas yaitu, 1) prosedur pengambilan sampel ini lebih memuaskan dan tepat sasaran,. 2) Keterbatasan waktu, biaya, dan tenaga tim peneliti, 3) Pengambilan sampel nonprobabilitas merupakan satu-satunya alternatif yang cocok (feasible) apabila populasi total tidak tersedia atau tidak di ketahui peneliti (Cooper dan Schindler, 2001 dalam (Wahyudi, \& Suryanadi, 2019.)

Jumlah responden yang berhasil dihimpun peneliti adalah sebanyak dua puluh empat responden, jumlah tidak sesuai dengan estimasi peneliti yang dapat menghimpun kurang lebih tiga puluh lima pelaku usaha terasi. Kondisi ini disebabkan karena pada saat dilakukan penelitian, calon responden menolak diwawancara, dan sebagian lain sedang tidak melakukan kegiatan produksi dan memilih melaut sehingga peneliti tidak dapat melakukan interview terhadap calon responden.

\section{Hasil Penelitian}

\section{Analisis Deskriptif}

Penelitian ini menggunakan analisis deskritptif dengan alat ukur mean, mean digunakan untuk mengetahui bobot rata rata jawaban dari responden terhadap setiap pernyataan pada masing masing variabel, maupun tiap dimensi dan indikator dari variabel tersebut (Yuwono et al., 2007) . Hasil statistik deskriptif dapat dilihat pada tabel berikut ini :

Tabel 1. Analisis Statistik Deskriptif

\begin{tabular}{|c|c|c|}
\hline Indikator & Mean & Standar Deviasi \\
\hline $\begin{array}{l}\text { Pemasaran tradisional (mouth to mouth marketing) tidak cukup } \\
\text { dalam menjangkau pasar yang lebih luas. }\end{array}$ & 4,50 & 0,511 \\
\hline Pengqunaan sosial media membantu pemasaran produk. & 4,33 & 0,482 \\
\hline $\begin{array}{l}\text { Pengetahuan pemasaran global diperlukan dalam memasarkan } \\
\text { produk internasional. }\end{array}$ & 3,83 & 0,381 \\
\hline $\begin{array}{l}\text { Bunga pinjaman perlu diturunkan agar dapat mengakses pinjaman } \\
\text { modal. }\end{array}$ & 3,67 & 0,761 \\
\hline $\begin{array}{l}\text { Harga Alat produksi yang mahal dapat mengahambat } \\
\text { pengembangan produktivitas pembuatan terasi. }\end{array}$ & 3,50 & 0,885 \\
\hline $\begin{array}{l}\text { Bank perlu mempermudah administrasi peminjaman kredit usaha } \\
\text { kecil. }\end{array}$ & 2,79 & 1,02 \\
\hline Banyak pesaing yang mampu membuat terasi yang lebih baik. & 3,63 & 0,924 \\
\hline Membuat terasi cukup mudah dan bisa dilakukan siapa saja. & 3,92 & 0,717 \\
\hline Teknologi pembuatan terasi harus dikuasai untuk efisiensi. & 4,08 & 0,717 \\
\hline Omset yang diterima sejauh ini belum maksimal. & 3,67 & 0,917 \\
\hline $\begin{array}{l}\text { Profit yang diperoleh cukup memenuhi kebutuhan hidup pelaku } \\
\text { usaha. }\end{array}$ & 4,08 & 0,822 \\
\hline Kurun waktu balik modal (BEP) Pengolahan terasi cukup cepat. & 3,79 & 0,884 \\
\hline
\end{tabular}

Sumber : data primer diolah, 2019

Dengan melihat nilai mean, indikator "pemasaran dari mulut ke mulut dirasakan tidak cukup untuk menjangkau pasara yang lebih luas" memiliki nilai mean tertinggi yaitu 4,50. Persepsi pada indikator tersebut memiliki dampak yang cukup besar bagi pelaku usaha terasi Kota Langsa dalam meningkatkan kinerja usahnya. Mengandalkan pemasaran tradisional saja dirasakan sangat kurang dalam meningkatkan omset pelaku usaha. Sedangkan indikator yang dirasakan memiliki dampak minimal bagi responden adalah "Bank perlu mempermudah administrasi peminjaman kredit usaha kecil", berdasarkan hasil pengamatan peneliti responden lebih memilih mengambil modal dari koperasi dan modal sendiri/keluarga, dan cenderung mengabaikan rumitnya administrasi peminjaman di bank pemerintah.

Berdasarkan hasil skor standar deviasi, "Bank perlu mempermudah administrasi peminjaman kredit usaha kecil" memiliki skor tertinggi yaitu 1,02. Dimana persepsi mengenai kerumitan administrasi tidak dirasakan 
secara merata atau dirasakan secara berbeda beda oleh pelaku usaha terasi di Kota Langsa, artinya tidak semua pengrajin sepakat bahwa hal tersebut menganggu kegiatan produksi terasi. Sedangkan skor deviasi terendah ada pada "Pengetahuan pemasaran global diperlukan dalam memasarkan produk internasional" dengan skor 0,381, yang berarti bahwa hal pengetahuan pemasaran global dirasakan merata sangat diperlukan bagi pengrajin agar dapat meningkatkan penjualan dan kinerja usaha.

\section{Uji Validitas dan Reliabilitas}

Uji instrumen yang pertama adalah uji validitas, uji Validitas merupakan suatu alat ukur untuk melihat apakah suatu alat ukur dapat mengukur apa yang sebenarnya ingin diukur (Cooper, D.R. and Schindler, 2001). Pengujian validitas diterapkan pada uji construct validity, untuk mengetahui apakah alat ukur sudah memenuhi atau sesuai dengan teori (Sekaran, 2000)

Tabel 2. Hasil Uji Reliablitas

\begin{tabular}{lll}
\hline Variabel & Nilai Alpha & Keterangan \\
\hline Pemasaran & 0,640 & Diterima \\
Persaingan & 0,629 & Diterima \\
Permodalan & 0,662 & Diterima \\
Kinerja & 0,642 & Diterima \\
\hline
\end{tabular}

Sumber : data primer diolah

Berdasarkan dari hasil uji reliabilitas, ketiga variabel baik variabel pemasaran, persaingan, maupun permodalan dan kinerja memiliki nilai alpha di atas 0,60. Dimana dengan nilai alpha lebih besar dari 0,60 variabel penelitian memenuhi uji validitas (Imam Ghazali, 2003)

Uji reliabilitas adalah alat untuk mengukur suatu kuesioner yang merupakan indikator dari variabel atau konstruk (Imam Ghazali, 2003). Nilai yang digunakan adalah corrected item total correlation yang lebih besar daripada nilai $r$ tabel. Dimana skor $r$ tabel dalam penelitian ini adalah 0,3438. Nilai item-total-correlation lebih kecil dari 0.50 tetap dapat diterima jika item-item yang di eliminasi akan menghasikan koefisien cronbach's alpha yang lebih kecil (Sekaran, 2000)

Tabel 3. Uji Validitas

\begin{tabular}{llll}
\hline Kode Indikator & R hitung & R tabel & Keterangan \\
\hline Pem1 & 0,485 & 0,3438 & Valid \\
Pem2 & 0,395 & 0,3438 & Valid \\
Pem3 & 0,466 & 0,3438 & Valid \\
Mod1 & 0,733 & 0,3438 & Valid \\
Mod2 & 0,411 & 0,3438 & Valid \\
Mod3 & 0,358 & 0,3438 & Valid \\
Per1 & 0,664 & 0,3438 & Valid \\
Per2 & 0,408 & 0,3438 & Valid \\
Per3 & 0,408 & 0,3438 & Valid \\
Kinerja1 & 0,801 & 0,3438 & Valid \\
Kinerja2 & 0,482 & 0,3438 & Valid \\
Kinerja3 & 0,884 & 0,3438 & Valid \\
\hline
\end{tabular}

Sumber : data primer diolah, 2019

Berdasarkan dari hasil uji reliabilitas, indikator dalam penelitian ini memiliki skor $r$ hitung lebih besar dari $r$ tabel, sehingga semua indikator tersebut dapat diproses lebih lanjut untuk pengujian selanjutnya. 


\section{Uji Hipotesis}

Tabel 4. Uji signifikansi parsial

\begin{tabular}{|c|c|c|c|c|c|c|}
\hline \multicolumn{2}{|c|}{ Model } & \multicolumn{5}{|c|}{ Standardized } \\
\hline & & $B$ & Std. Error & $\frac{\text { Coefficients }}{\text { Beta }}$ & $t$ & Sig. \\
\hline \multirow[t]{4}{*}{1} & (Constant) & 6,996 & 2,688 & & 2,602 & 017 \\
\hline & Pemasaran & -241 & 237 &,- 143 & $-1,020$ &, 320 \\
\hline & Permodalan & ,746 & 120 & ,866 & 6,221 &, 000 \\
\hline & Persaingan &, 015 & , 139 &, 016 & , 109 & ,914 \\
\hline
\end{tabular}

Sumber : data primer diolah, 2019

Berdasarkan hasil dari pengolahan data tersebut strategi pemasaran tidak berpengaruh positif dan signifikan terhadap kinerja UKM dengan nilai t hitung adalah $-1,020$ dan signifikansi $>0,05(0,320)$. Permodalan berpengaruh poditif dan signifikan terhadap kinerja UKM dengan nilai t hitung 6,221 dan signifikansi 0,000. Dan variabel situasi persaingan berpengaruh positif dan tidak signifikan terhadap kinerja UKM, dengan nilai t hitung 0,109 dan signifikansi 0,914 yang nilainya $>0,05$

\section{Pembahasan}

\section{Pengaruh Strategi Pemasaran Terhadap Kinerja UKM}

Berdasarkan hasil pengujian hipotesis di atas, terlihat bahwa variabel pemasaran tidak berpengaruh secara signifikan terhadap kinerja usaha pengrajin terasi. Berdasarkan hasil tinjauan peneliti, meskipun pada umumnya pelaku usaha terasi sepakat bahwa pemasaran tradisional tidaklah cukup untuk meningkatkan penjualan, akan tetapi responden dalam melakukan kegiatan penjualan sudah memiliki saluran distribusi tetap seperti agen penyalur yang siap menampung hasil produksi para pelaku usaha terasi, sehingga variabel pemasaran tidak berdampak secara signifikan dalam persepsi responden, dengan demikian hipotesis pertama ditolak.

\section{Pengaruh Permodalan terhadap Kinerja UKM}

Permodalan berpengaruh positif dan signifikan terhadap kinerja usaha pengrajin terasi (sig 0.00$)$ hasil pengujian hipotesis dua konsisten dengan penelitian yang telah dilakukan oleh sejumlah penelitian sebelumnya bahwa permodalan masih menjadi masalah utama dalam peningkatan kinerja usaka kecil dan menengah di Indonesia. (Indarti \& Langenberg, 2004; Irjayanti \& Azis, 2013; Kumar et al., 2012; Wahyuningrum, Sukmawati, \& Kartika, 2016; Yuwono et al., 2007). Keterbatasan modal yang dimiliki, dan terbatasnya akses permodalan ke pihak perbankan menjadi masalah tersendiri bagi pelaku usaha kecil. Dengan demikian, hipotesis ke dua dalam penelitian ini diterima.

\section{Pengaruh Situasi Persaingan Terhadap Kinerja}

Pada pengujian hipotesis ke tiga, situasi persaingan tidak berdampak positif dan signifikan $(0,914)$ hal ini berdasarkan pengamatan peneliti, bahwa profesi pembuat terasi adalah profesi secara turun temurun dan telah menjadi budaya penduduk pesisir pantai, sehingga ada tidak adanya pesaing dilingkungan pelaku usaha terasi tidak berdampak signifikan karena profesi atau usaha tersebut sudah sudah menjadi bagian kebudayaan hidup penduduk sekitar.

\section{Kesimpulan}

Berdasarkan hasil dari pembahasan tersebut di atas, permodalan masih menjadi kendala utama bagi pelaku usaha terasi di Kota Langsa, serta pelaku usaha kecil dan menengah lainnya, masalah permodalan yang dihadapi pelaku usaha terasi adalah teknologi peroduksi yang sederhana dan keterbatasan sumber dana. Masalah yang berhubungan dengan permodalan yang dikeluhkan oleh responden adalah minimnya bantuan modal peralatan dari instansi pemerintah serta keengganan mengakses kredit perbankan, masalah permodalan 
menyebabkan pelaku usaha terasi sulit berkembang, karena tidak mampu menangani permintaan pasar dalam skala pasar yang lebih luas, sehingga produk terasi Kota Langsa tidak dikenal secara luas dalam skala nasional.

Berdasarkan survei wawancara, pelaku usaha mengharapkan perhatian serius dari pemerintah dalam mendukung kegiatan usaha terasi yang menjadi tulang punggung kawasan pesisir, seperti bantuan modal peralatan yang didistribusikan secara merata kepada pelaku usaha dan kejelasan informasi bantuan pemerintah yang diekspos di tempat publik sehingga memudahkan pelaku usaha mendapatkan kejelasan mengenai program bantuan pemerintah. Studi ini memerlukan pendalaman lebih lanjut mengingat bahwa jumlah responden yang terbatas beserta lingkup usaha kecil yang diteliti tidak dapat digeneralisasikan terhadap jenis usaha kecil lainnya.

\section{Daftar Pustaka}

A. Utaminingsih. (2016). Pengaruh Orientasi Pasar, Inovasi, Dan Kreativitas Strategi Pemasaran Terhadap Kinerja Pemasaran Pada Ukm Kerajinan Rotan Di Desa Teluk Wetan, Welahan, Jepara. Media Ekonomi Dan Manajemen, 31(2), 77-87.

Adawiyah, W. R. (2011). Faktor Penghambat Pertumbuhan Usaha Mikro Kecil Menengah ( UMKM ): Studi di Kabupaten Banyumas. Seminar Nasional \& Call For Papers (SCA-1), 740/5000, 1-18.

BPS. (2019). No Title. Retrieved from https://aceh.bps.go.id/

Cooper, D.R. and Schindler, P. S. (2001). Bussiness Research Method. London: McGraw-Hill Higher Education.

Ediraras, D. (2010). Akuntansi Dan Kinerja Ukm. Jurnal IImiah Ekonomi Bisnis, 15(2), 152-158.

Hadiyati, E. (2011). Kreativitas dan Inovasi Berpengaruh Terhadap Kewirausahaan Usaha Kecil. Jurnal Manajemen Dan Kewirausahaan, 13(1).

Imam Ghazali. (2003). Analisis Multivariate Dengan Menggunakan SPSS (dua). Semarang: Badan Penerbit Universitas Diponegoro.

Indarti, N., \& Langenberg, M. (2004). Factors affecting business success among SMEs: empirical evidences from Indonesia. Second Bi-Annual European Summer ..., (August), 1-15.

Irjayanti, M., \& Azis, A. M. (2013). Barrier Factors and Potential Solutions for Indonesian SMEs. Procedia Economics and Finance, 4(Icsmed), 3-12.

Kumar, R., Sheetal, \& Sangeeta. (2012). Marketing Strategies of Small and Medium Enterprises: A Sample Survey. International Journal of Management Sciences, 01(02), 60-71.

Persepsi, P., Box, B., Wahyudi, L., \& Suryanadi, P. (n.d.). Analisis City Branding Kabupaten Sukoharjo Sebagai Kota Jamu : $14-27$.

Purwaningsih, R., \& Kusuma Damar, P. (2015). Analisis Faktor-faktor yang mempengaruhi Kinerja Usaha Kecil dan Menengah (UKM) dengan Metode Structural Equation Modeling (Studi kasus UKM berbasis Industri Kreatif Kota Semarang). E-Journal Undip, 1(1), 7-12.

Samir, A., \& Larso, D. (2002). Identifikasi Faktor-Faktor Yang Mempengaruhi Kinerja UKM Catering Di Kota Bandung. Journal of Technology Management, 10(2).

Sekaran, U. (2000). Research Methods for Business: A Skill Business Approach. New York: John Wiley and Sons.

Tambunan, T. (2005). Promoting small and medium enterprises with a clustering approach: A policy experience from Indonesia. Journal of Small Business Management, 43(2), 138-154.

Wahyuningrum, P., Sukmawati, A., \& Kartika, L. (2016). Peningkatan Kinerja Usaha Kecil dan Menengah (UKM) Kluster Kerajinan di Kota Depok Menggunakan The House Model. Jurnal Manajemen Dan Organisasi, 5(2), 154.

Wardi, Y., Susanto, P., \& Abdullah, N. L. (2017). Orientasi Kewirausahaan pada Kinerja Usaha Kecil dan Menengah (UKM) Sumatera Barat: Analisis Peran Moderasi dari Intensitas Persaingan, Turbulensi Pasar dan Teknologi. Jurnal Manajemen Teknologi, 16(1), 46-61.

Wibowo, D. H., Arifin, Z., \& Sunarti, . (2015). Analisis Strategi Pemasaran Untuk Meningkatkan Daya Saing 
UMKM (Studi pada Batik Diajeng Solo). Jurnal Administrasi Bisnis, 29(1), 59-66.

Yuwono, R., Retno, R. R., Bisnis, P. M., Manajemen, P. S., Petra, U. K., \& Siwalankerto, J. (2007). Analisa Faktor-Faktor Penghambat Pertumbuhan Di Jawa Timur. 1(3). 